\title{
Ontogeny and autecology of an Early Cretaceous trigoniide bivalve from Neuquén Basin, Argentina
}

\author{
Javier Echevarría \\ Acta Palaeontologica Polonica 59 (2), 2014: 407-420 doi: http://dx.doi.org/10.4202/app.2012.0042
}

Understanding ontogenetic variation is fundamental for adequate species definition and is the key for recognizing evolutionary relevant processes like heterochrony or developmental constraints. The larval and post-larval shell ontogeny and the ecology of the trigoniide bivalve Myophorella garatei are described in this paper. The species occurs in offshore transition facies of the late Valanginian Pilmatue Member of the Agrio Formation in the Neuquén Basin, Argentina. The larval shell has a rather small prodissoconch I; and if prodissoconch II is present, it is rather weakly developed. From these data, a larval stage of low dispersal capability is inferred for Myophorella garatei, either short-lived planktotrophic or nonplanktotrophic. The study of post-larval development included general shell shape and ornamentation. To assess general shell shape a geometric morphometric analysis was performed on the lateral view, together with a study of allometry for the shell width. As a result, two main allometric stages of development could be identified. During the first stage a relative size reduction of the area co-occurs with a slight elongation of the shell, while the second stage is marked by dorsal bending of the shell and an increase on relative width. Ornamentation was examined qualitatively, but also a geometric morphometric analysis was performed on the flank costae. The first two flank costae are subconcentric; from the third costa onwards they become oblique, intially changing from more curved to less curved shapes, while on a third stage they show the opposite trend. Finally, a general interpretation of the adaptive morphology of adult shell was performed, concluding that $M$. garate $i$ was adapted to low energy, soft bottom environments, and probably lived with the posterior straight margin levelled at the water-sediment interface.

Key words: Mollusca, Bivalvia, Trigoniida, ontogeny, larval development, shell growth, allometry, life habits, Cretaceous, Argentina.

Javier Echevarría [javierechevarria@fcnym.unlp.edu.ar], Museo de La Plata, División Paleozoología de Invertebrados; Consejo Nacional de Investigaciones Científicas y Técnicas (CONICET), Paseo del Bosque S/N, La Plata (1900), Provincia de Buenos Aires, Argentina. 
This is an open-access article distributed under the terms of the Creative Commons

Attribution License (for details please see creativecommons.org), which permits unrestricted use, distribution, and reproduction in any medium, provided the original author and source are credited.

For Full text $(1,054.3 \mathrm{kB})$ 